\title{
First documented record of Cerulean Warbler Setophaga cerulea (Parulidae) in Brazil
}

\author{
Fernando Bittencourt de Farias ${ }^{1,3} \&$ Larissa Dalpaz ${ }^{2}$
}

\author{
Servidão Brasiliano 123, Campeche, 88063-515, Florianópolis, SC, Brazil. \\ Programa de Pós-graduação em Ecologia, Universidade Federal de Santa Catarina - UFSC, Campus Universitário, Florianópolis, SC, Brazil. \\ Corresponding author: fernando-farias@hotmail.com
}

Received on 14 August 2018. Accepted on 04 July 2019.

\begin{abstract}
Cerulean Warbler (Setophaga cerulea; Parulidae) is a "Vulnerable" species which breeds in North America and migrates to winter in South America. Here we present the first documented record of the species in Brazil. One male was photographed foraging in the canopy of secondary forest on Santa Catarina island, south Brazil, on 07 April 2018. At the time of the record the species was expected to be on migration north to North America. Since the individual was heading south it is assumed that it was lost. This record can then be potentially explained by the vagrancy theory of reverse migrants.
\end{abstract}

KEY-WORDS: Atlantic Forest, mariquita-azul, migration, Santa Catarina, vagrancy.

The Cerulean Warbler (Setophaga cerulea) is a migratory passerine of the Parulidae family and is listed as "Vulnerable" by the IUCN Red List of Threatened Species (Birdlife International 2016). The species breeds in eastern U.S.A. and Canada during the northern hemisphere spring and summer. After that it migrates south to winter on the eastern slopes of the Andes, from southern Colombia and Venezuela to Ecuador, southeastern Peru and northern Bolivia (Skolnik et al. 2012). On its way to South America it is a passage migrant through the Atlantic coast of Central America. In its wintering area individuals have most often been observed within a narrow elevation range of 500-2000 m (Robbins et al. 1992).

To date, Cerulean Warbler was included on the secondary list of Brazilian birds based on two visual records, which were without supporting physical evidence (Piacentini et al. 2015). These two previous undocumented records were on October 1980, in Serra do Tinguá, Rio de Janeiro state, southeastern Brazil, at 330 m a.s.l. (Scott \& Brooke 1985); and during fieldwork in Monte Belo, Minas Gerais state, southeastern Brazil, with no precise date, but between 1981 and 1986 (Pacheco et al. 2014).

Here we present the first documented record of Cerulean Warbler for Brazil (Fig. 1). One adult male was seen actively foraging between the leaves of an Inga tree (Inga sp.) on 07 April 2018 in a forest patch at the Parque Natural Municipal do Maciço da Costeira, Florianópolis, Santa Catarina $\left(27^{\circ} 38^{\prime} 45.61^{\prime \prime}\right.$; $48^{\circ} 29^{\prime} 29.75^{\prime \prime W}$; Fig. 2). The individual was observed foraging between 9:40 and 10:00 h. The foraging mode observed was foliage gleaning, which is regularly observed for the species in North America (Jones et al. 2000). Repeated visits to the same location for several days following the first record failed to relocate the species.

The forest fragment where the species was recorded is a patch of secondary forest located behind a quarry in the south of Santa Catarina island. The individual was emitting some calls spontaneously but did not react to playback of the species. The lack of vocal response is an indicative that the individual was not defending a territory (Catchpole \& Slater 2003), which was expected since this is a non-breeding area for the species and also out of the reproductive season.

Our record represents not only the first documented record in Brazil, but the most austral one. The recorded individual can be considered as a vagrant as it was outside its regular migratory route (Veit 2000). This is similar for other records of North American warblers found in Brazil (Deconto \& Vallejos 2017, Somenzari et al. 2018). At the time of record the individual was expected to be returning to North America, but it is postulated it was heading in the opposite direction. This is the second case of a North American warbler recorded in Santa Catarina at a time when they are found in North America (Garcia 2016). Considering these aspects, our conclusion is that these records can be explained by the vagrancy theory of reverse migrants (Gilroy \& Lees 2003), in which birds deviate by around 180 degrees of their route, thus going in the opposite direction than expected (Alerstam 1990). 


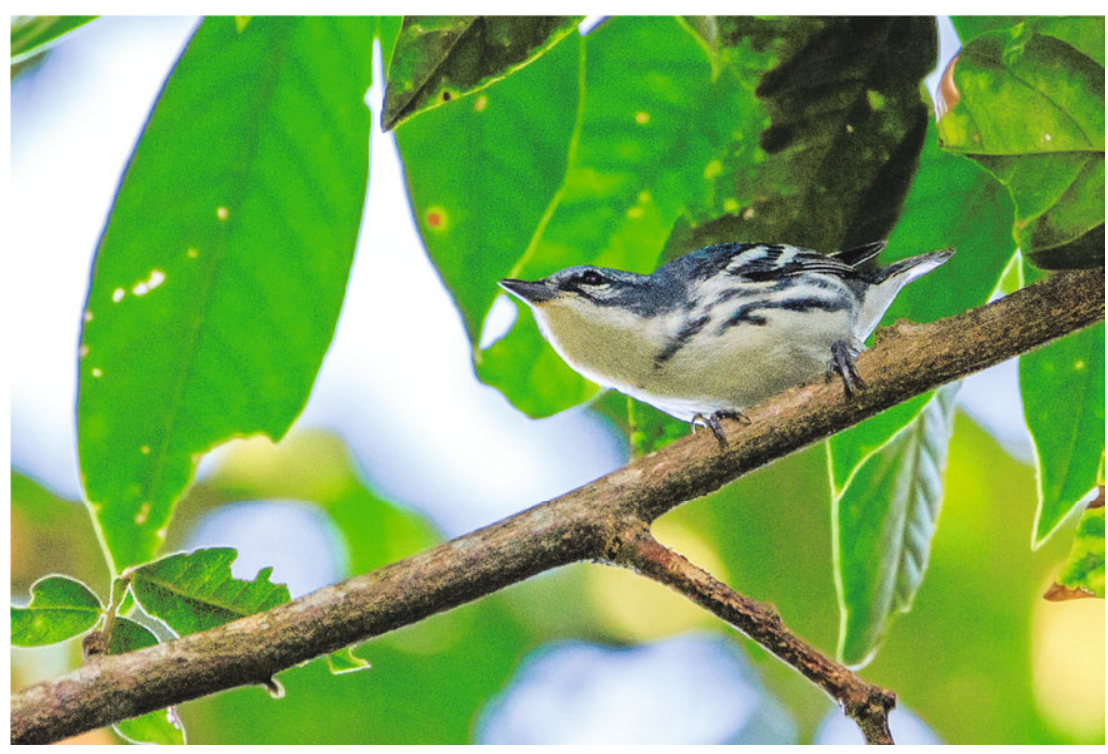

Figure 1. Adult male Cerulean Warbler (Setophaga cerulea) perched on a branch of an Inga tree, photographed on 07 April 2018 in Florianópolis, Santa Catarina, Brazil. Photo author: Fernando B. de Farias.

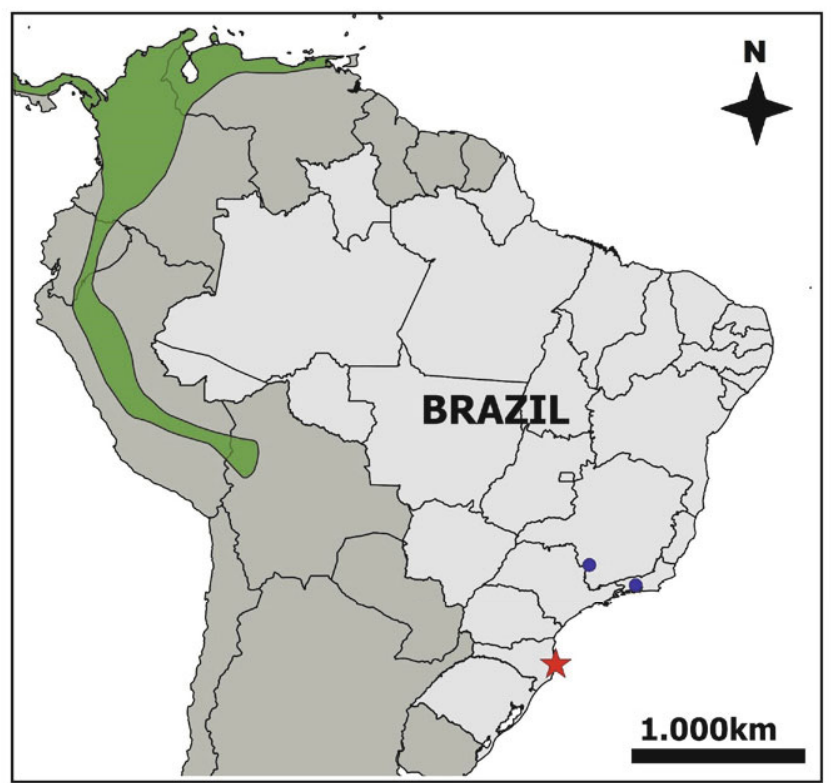

Figure 2. Winter distribution of the Cerulean Warbler (Setophaga cerulea; green area) with the two undocumented records in southeastern Brazil (blue dots) and the new record in Santa Catarina, southern Brazil (red star). Adapted from Birdlife International.

Also, our finding reinforces the importance of maintaining monitoring efforts even in urban forest fragments and especially in poorly-sampled areas. Records such as the one reported here are useful to adding information to our understanding of vagrancy theories (Gilroy \& Lees 2003) and identifying the paths and deviations of bird migration.

\section{ACKNOWLEDGEMENTS}

Fernando Pacheco kindly provided some of the literature used in this article. We are also grateful to Guilherme Willrich, Vitor Q. Piacentini and Thomas Worthington who reviewed the manuscript, and Guilherme Willrich who helped with the map.

\section{REFERENCES}

Alerstam T. 1990. Ecological causes and consequences of bird orientation. Experientia 46: 405-415.

BirdLife International. 2016. Setophaga cerulea. The IUCN Red List of Threatened Species. http://iucnredlist.org/details/22721740/0 (Access on 26 June 2018).

Catchpole C.K. \& Slater P.J. 2003. Bird song: biological themes and variations. Cambridge: Cambridge University Press.

Deconto L.R. \& Vallejos M.A.V. 2017. Primeiro registro documentado de Setophaga virens (Aves: Parulidae) no Brasil. Atualidades Ornitológicas 198: 14-17.

Garcia D.H. 2016. WA2166503, Setophaga striata (Forster, 1772). http://www.wikiaves.com/2166503 (Access on 03 July 2018).

Gilroy J.J \& Lees A.C. 2003. Vagrancy theories: are autumn vagrants really reverse migrants? British Birds 96: 427-438.

Jones J., Perazzi P.R., Carruthers E.H. \& Robertson R.J. 2000. Sociality and foraging behavior of the Cerulean Warbler in Venezuelan shade-coffee plantations. Condor 102: 958-962.

Pacheco J.F., Parrini R. \& Tavares D. 2014. Avifauna da RPPN Fazenda Lagoa e entorno, p. 164-172. In: Laurindo R.S., Novaes R.L.M. \& Vieira M.C.W (eds.). RPPN Fazenda: educação, pesquisa e conservação da natureza. Monte Belo: Ismecn.

Piacentini V.Q., Aleixo A., Agne C.E., Maurício G.N., Pacheco J.F., Bravo G.A., Brito G.R.R., Naka L.N., Olmos F., Posso S., Silveira L.F., Betini G.S., Carrano E., Franz I., Lees A.C., Lima L.M., Pioli D., Schunck F., Amaral F.R., Bencke G.A., Cohn-Haft M., Figueiredo L.F.A., Straube F.C. \& Cesari E. 2015. Annotated checklist of the birds of Brazil by the Brazilian Ornithological Records Committee. Revista Brasileira de Ornitologia 23: 91-298.

Robbins C.S., Fitzpatrick J.W. \& Hamel P.B. 1992. A warbler in trouble: Dendroica cerulea, p. 549-562. In: Hagan-III J.M. \& Johnston D.W. (eds.). Ecology and conservation of Neotropical migrant landbirds. Washington: Smithsonian Institution Press.

Scott D.A. \& Brooke M.L. 1985. The endangered avifauna of 
southeastern Brazil: a report on the BOU/WWF expeditions of 1980/81 and 1981/82, p. 115-139. In: Diamond A.W. \& Lovejoy T.E. (eds.). Conservation of tropical forest birds. Cambridge: International Council for Bird Preservation.

Skolnik B., Wiedenfeld D., Dettmers R., Aucca C., Daza L., Valle H., Sornoza F., Robayo J., Diaz D., Jane F., Lebbin D. \& Hame P.B. 2012. Conservation planning and accomplishments for protection of Cerulean Warbler (Setophaga cerulea) nonbreeding habitat. Ornitología Neotropical 23: 319-329.

Somenzari M., Amaral P.P., Cueto V.R., Guaraldo A.C., Jahn A.E.,
Lima D.M., Lima P.C., Lugarini C., Machado C.G., Martinez J., Nascimento J.L.X., Pacheco J.F., Paludo D., Prestes N.P., Serafini P.P., Silveira L.F., Sousa A.E.B.A., Sousa N.A., Souza M.A., Telino-Jr. W.R. \& Whitney B.M. 2018. An overview of migratory birds in Brazil. Papéis Avulsos de Zoologia 58: e20185803.

Veit R.R. 2000. Vagrants as the expanding fringe of a growing population. Auk 117: 242-246.

Associate Editor: Leandro Bugoni. 